LOCAL WISDOM, $12(2):$ 156-166, 2020
Local Wisdom Scientific Online Journal
ISSN: 2086-3764

\title{
The Local Wisdom Study of Luan And Teben Concept on Balinese Ethnic Houses
}

\author{
Case Study: Balinese Ethnic Houses in Denpasar, Bali
}

\section{Kadek Merta Wijaya ${ }^{*}$}

1. Department of Architecture, Universitas Warmadewa, Bali

Corresponding Author: amritavijaya@gmail.com

\begin{tabular}{ll}
\hline Keywords: & Abstract \\
Balinese ethnichouses, & Sanga Mandala is a concept that divide the layout of lowland Balinese \\
contemporary luan and & house into nine zones. The intersection of two main axes, the ritual \\
teben, luan and teben & axis and the natural axis, forms the concept of Sanga Mandala. These \\
orientation, luan and & axes have two poles called hulu/luan (mountain direction) and teben \\
teben zoning. & (sea direction). Along with times, the realization of Sanga Mandala in \\
& the form of buildings and zoning underwent a transformation in \\
& response to the increase in household members, modern mindset of \\
the citizen, and tendency to follow contemporary trends. Changes to & the zoning system that still follow the rules of traditional Balinese \\
architecture are zones of sacred and ritual functions. With the & development of modern mindset of the citizen, we can find those \\
phenomena in Denpasar. This study aimed at examining the \\
meaning of luan and teben on Balinese ethnic house layout in \\
Denpasar. There is an interesting phenomenon that relates to the \\
meaning of luan and teben in contemporary life. This study used \\
interpretative naturalistic research method by emphasizing the \\
empirical aspects of sensual, ethical, emic, logical, and \\
transcendental. The results showed that there was a pattern of \\
meaning on luan and teben in the conception of zoning, \\
transformation of spaces and buildings, orientation of the building \\
mass, as well as producing a pattern of meaning in zoning and ritual \\
functions as the most important part in the residential space layout of \\
Balinese ethnic houses in the midst of the development of Denpasar.
\end{tabular}

DOI: https://doi.org/10.26905/lw.v12i2.4276

@ 2017 The Authors. Published by GKAK UNMER Malang

Article History

$\begin{array}{lll}\text { Received } & : & \text { June 10, } 2020 \\ \text { Accepted } & : & \text { June 29, } 2020 \\ \text { Published } & : & \text { July 15, } 2020\end{array}$

\section{INTRODUCTION}

The conception of luan and teben is an ancient cosmological concept that developed in Bali. This is in accordance with the statement of (Siwalatri, 2017) which states that the people of Bali Aga (Native Balinese) use the concept of kaja-kelod or luan-teben in determining the spatial hierarchy. This concept was first recognized in the patterns of traditional Balinese houses in mountainous areas (Bali Aga). Arimbawa \& Santhyasa (2010) states that the concept of traditional community activities is generally related to two 
aspects, namely religious activities (sacred) and social activities (profane), which are classified in traditional architectural spatial planning. The hierarchy of these two aspects is manifested in the Utama / Luan / sacred and Nista / Teben / profane spatial concepts. According to Wijaya (2019), different from the Bali Aga settlement which are usually linearly patterned, the Balinese ethnic houses in the lowlands are centered on natah (plaza) with the main orientation being the directions of kaja (Mount Agung) and kangin (sunrise). Luan is a building orientation that has a main or high value such as mountains, hills or the direction of sunrise. While teben is in opposition to the direction of the land such as the direction of the sea/the direction of the lowlands or the direction of sunset.

The development of this concept in the Balinese ethnic houses in the lowlands was by combining two pairs of axes that have luan and teben orientation. The first axis is the ritual axis in the form of the rising and setting direction of the sun and the other axis is the natural axis in the form of mountain and sea orientation. This merger forms the concept of the Sanga Mandala pattern which divides the zoning of residential houses into nine zones. The nine zones have the utama and nista orientation, utama is in the direction of kaja-kangin which is intended for the sanctuary zone while nista is in the kelod-kauh as lebuh or entrance to the yard. The space between the kaja-kangin and kelod-kauh zones is "the yard" or plaza called natah. This is in accordance with Wijaya's statement, that natah is the orientation point of building masses which forms a centralized pattern (Wijaya, 2019) and according to Paramadhyaksa (2015), natah is a "yard" as a connecting point for three major cosmic axes, namely the kaja-kelod (mountain-sea), the axis of kangin-kauh (sunrise and sunset), and the axis of the pertiwi-akasa (sky-earth).

Denpasar is one of the areas in Bali with a residential layout using the concept of Sanga Mandala. Sanga Mandala has a characteristic in which the house yard consists of several building groups (bale), the concept of nine plots and a combination of eight cardinal directions/Asta Dala and one midpoint/center guide the form of the layout (Indriani, 2018). In one yard of a Balinese ethnic house in the lowland consists of several building masses, namely a shrine, Bale Daja, Bale Dangin, Bale Dauh, Bale Delod (kitchen), and Jineng (rice storage). The buildings are centered on the natah (plaza). The yard boundaries are surrounded by walls or so-called penyengker, as well as entrances called angkul-angkul. The positions of the building are based on their level in the spatial structure of Sanga Mandala.

In current developments, Denpasar is the largest city in Bali which is experiencing a modernization. The layout of residential housing adjusts to the development of architecture that is undergoing a modernization. According to Indriani (2018), Balinese traditional architectural layout in Denpasar cannot be avoided from the demands of the development in activities and modernity. The building in the form of bale (Bale Daja, Dangin, Dauh and Delod) has a manifestation that is not like traditional architecture in general. There is an increase in supporting space and the merging of two building into one building. The increase in building mass due to the increasing number of family members in one of these residential housing. Additionally, there is the use of new building materials in lieu of old materials.

Transformation of spatial layout of Balinese ethnic houses in Denpasar on a macro and micro level still pays close attention to the zoning of Sanga Mandala. The addition of new space functions occurs mostly in Bale Daja, Bale Delod, and Bale Dauh, while Bale Dangin does not experience additional functions. Addition of space functions in the initial building in the form of a bedroom or bathroom. Usually, the increase in building mass is a consequence of the increase in the number of family members, especially sons who are married and still living in the house. This mass increase occurs in the luan or nista (the direction of kelod and kauh). From the description above, it can be interpreted that the conception of luan and teben is the orientation and zoning of Sanga Mandala in the spatial 
layout of Balinese ethnic houses in Denpasar which is still maintained as a cosmology of orientation.

The study aimed at interpreting the concepts of luan and teben on the spatial layout and building mass of Balinese ethnic houses in Denpasar. The variables studied were zoning of building masses, changes in space in the Balinese ethnic house's layout and orientation of each building mass through the approach of Sanga Mandala, luan and teben concepts, Tri Hita Karana, and the development of Balinese ethnic houses in Denpasar.

\section{RESEARCH METHODOLOGY}

The method used in studying the meaning or interpretation of luan and teben conceptions in the spatial layout of Balinese ethnic houses in Denpasar is interpretative naturalistic with approaches to the empirical aspects of sensual, logical empirical, also aspects of the meaning and belief of local communities (transedental) (Muhadjir, 2002). The approaches used in interpreting the concepts of luan and teben are (1) the Tri Hita Karana conception in architecture, namely the shrine (sanggah), the residential zone (human habitation) and the lebuh zone (the entrance area to the residential yard); (2) Rwabhineda's conception in architecture, which is the concept of luan and teben, is very important to be maintained in creating a harmonious relationship between sacred values and profane spaces; and (3) the belief in Balinese Hindu community in the power of niskala (noetic/unseen) in sekala (real/seen) and maintain luan as the main orientation. In this study, four case studies were chosen in East Denpasar because this region is an area that still maintains traditional architectural system compared to other areas in Denpasar, making it easier to interpret problems. Data collection method was done through unstructured interviews as a condition of naturalistic method, literature review in the form of luan and teben concepts, Tri Hita Karana, sacred and profane, and an understanding of the local people's perspective on luan and teben concepts. While the method of analysis was through identifying the physical condition of the residential housing, identifying the history of the construction of the housing, and dialoguing with the concepts that were previously formulated.

The locus of this research is in East Denpasar by taking 4 (four) case studies of ethnic Balinese residential. The case studies are as follows:

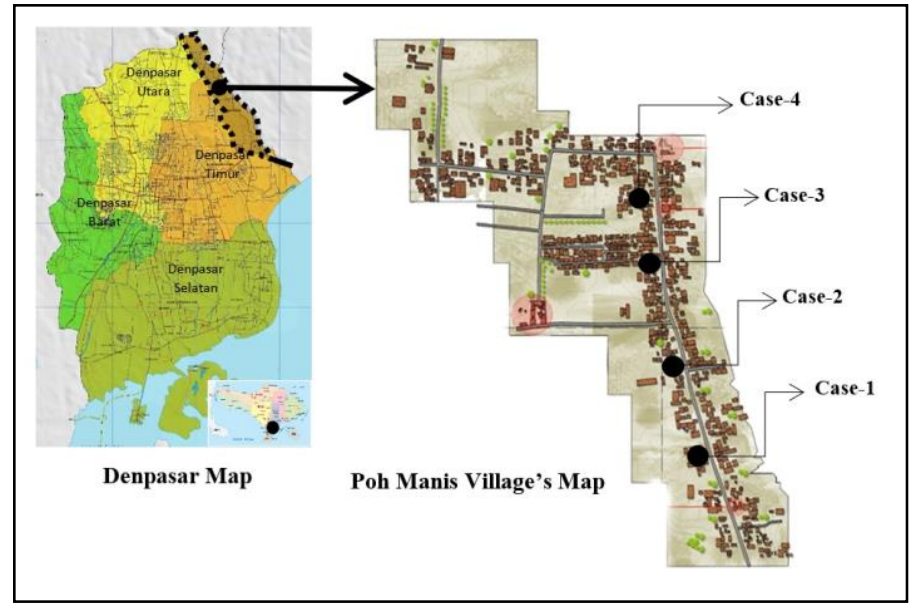

Figure 1. Research Location Map and Cases (Source: Author, 2020) 


\section{RESULTS AND DISCUSSION}

\section{Layout Conception of Balinese Ethnic Houses in The Lowlands}

The architecture of the residential layout of lowland Balinese ethnic houses is formed from several buildings with configurations and building patterns based on the concept of Sanga Mandala (Indriani, 2018). The substance of the spatial layout of Balinese ethnic houses in the lowlands is:

- Consisting of a cluster of buildings facing the Natah (plaza), the mass is Bale Daja, Bale Dangin, Bale Dauh, Bale Delod, Paon, Jineng (granary), Penunggun Karang, Sanggah and Pig Pen.

- The placement of the buildings is based on Sanga Mandala which divides the into nine zones. Each zone has a value, or a hierarchy of space divided into three zones, namely Utama, Madya, and Nista. Placement of buildings is based on the division of those three spatial hierarchies.

- Bale Daja is in the direction of kaja (luan/utama) and is intended as a place to sleep or rest for the head of the family or parents. The building is divided into two zones, namely the bedroom and the storage of ceremonial equipment.

- Bale Dangin is in the direction of kangin (luan/utama) and is used for traditional ceremonial or ritual activities

- Bale Dauh or often referred to as Bale Loji is in the direction of kauh (teben/nista) and is intended as a living room or as a bedroom area for unmarried sons.

- Bale Delod is also called Bale Semanggen which is used for ceremonial activities such as funerals or weddings

- Paon is in the direction of kelod kauh (teben/nista) which functions as kitchen and bedroom.

- Jineng or granery is a storage area for harvesting crops in the community with a wet and dry farming system with its position in the direction of delod (teben/nista)

- The pig pen is in delod (teben/nista) which is designated as a place to keep pigs.

The direction of orientation and function of the building units shows the concepts of utama and nista as a spatial hierarchy in the building layout of Balinese ethnic houses in the lowlands which is translated into luan and teben orientations. When looking from the formation of the spatial structure of Sanga Mandala which is created from two ritual and natural axes, each of which has a luan and teben orientation, the mass of buildings in the direction of luan are Sanggah (shrine), Bale Daja and Bale Dangin while those located in the direction of teben are Bale Dauh and Bale Delod. (see Figure 2).

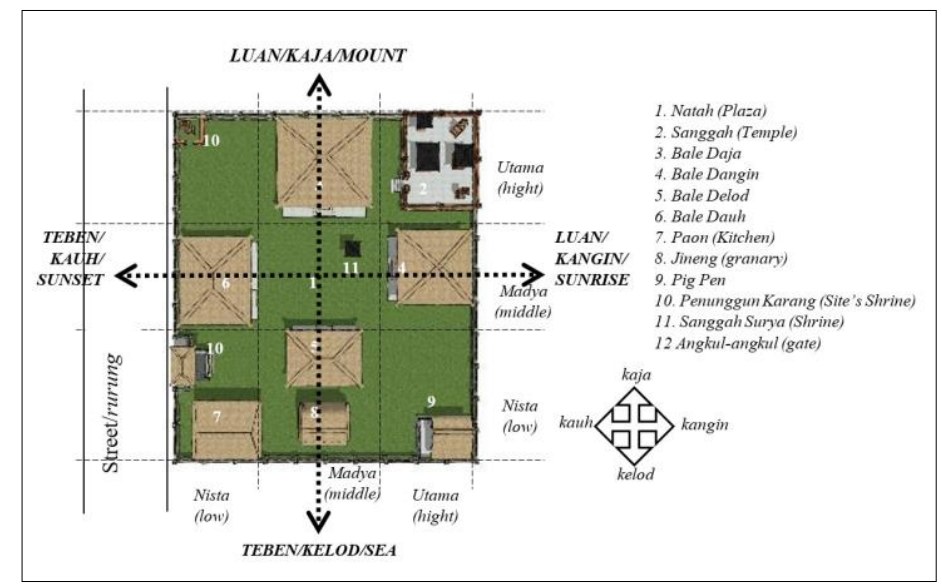

Figure 2. Sangamandala Concept in Balinese Ethnic Houses (Source: Modificatied of Wijaya (2018)) 
Parents are interpreted as someone who is respected and important in the family, so their space is in Bale Daja. The concept of parents in Hindu is called Guru Rupaka (part of Catur Guru). The concept of Guru Rupaka also aimed at ancestor who has given birth and guided a child to adulthood (Putra, Alfyananda Kunia Sumarmi \& Singgih, 2018). While the ritual activities for "humans" (weddings, otonan/balinese birthday, funerals) have meaning as a manifestation of "mental value" held in Bale Dangin. Ritual activities (psychological) carried out at Bale Dangin as the direction of the ritual axis, according to Rosada's statement that the concept of Luan and Teben has several orientations namely the earth/natural axis (Kaja/Luan-Kelod/teben) and the ritual axis (Kangin/Luan-Kauh/teben) (Rosada; Hariski, 2016). So, it can be said that the direction of Kaja and Kangin means luan (utama) which is interpreted in the form of Balinese ethnic residential architecture with Bale Daja and Bale Dangin. Activities like receiving guests and the residence of unmarried sons is a physical element and social relations which are held in Bale Dauh. The other physical activity is "cooking", therefore the Bale Delod is part of the direction of teben. Based on the description above, it can be said that the direction/zoning of luan is intended for activities that are spiritual or psychologically valuable, while the direction/zoning of teben for physical activities or values.

\section{Conception of Luan and Teben Based on Balinese Ethnic Houses}

The residential units studied consist of four cases, on average, one residential unit consists of a cluster of buildings that forms a pattern centered on an empty space, called natah (plaza). The Balinese ethnic houses in the lowlands consist of nine zones (sanga mandala) which are intended for shrine, Bale Daja, Bale Dangin, Bale Dauh and Bale Delod, Paon (kitchen), as well as other supporting building such as building units - typically sons who have been married and living with their parents, Perapean (social identity for the Pande caste), and Jineng - as the identity of the livelihoods of a farmer household. (see Figure 3).

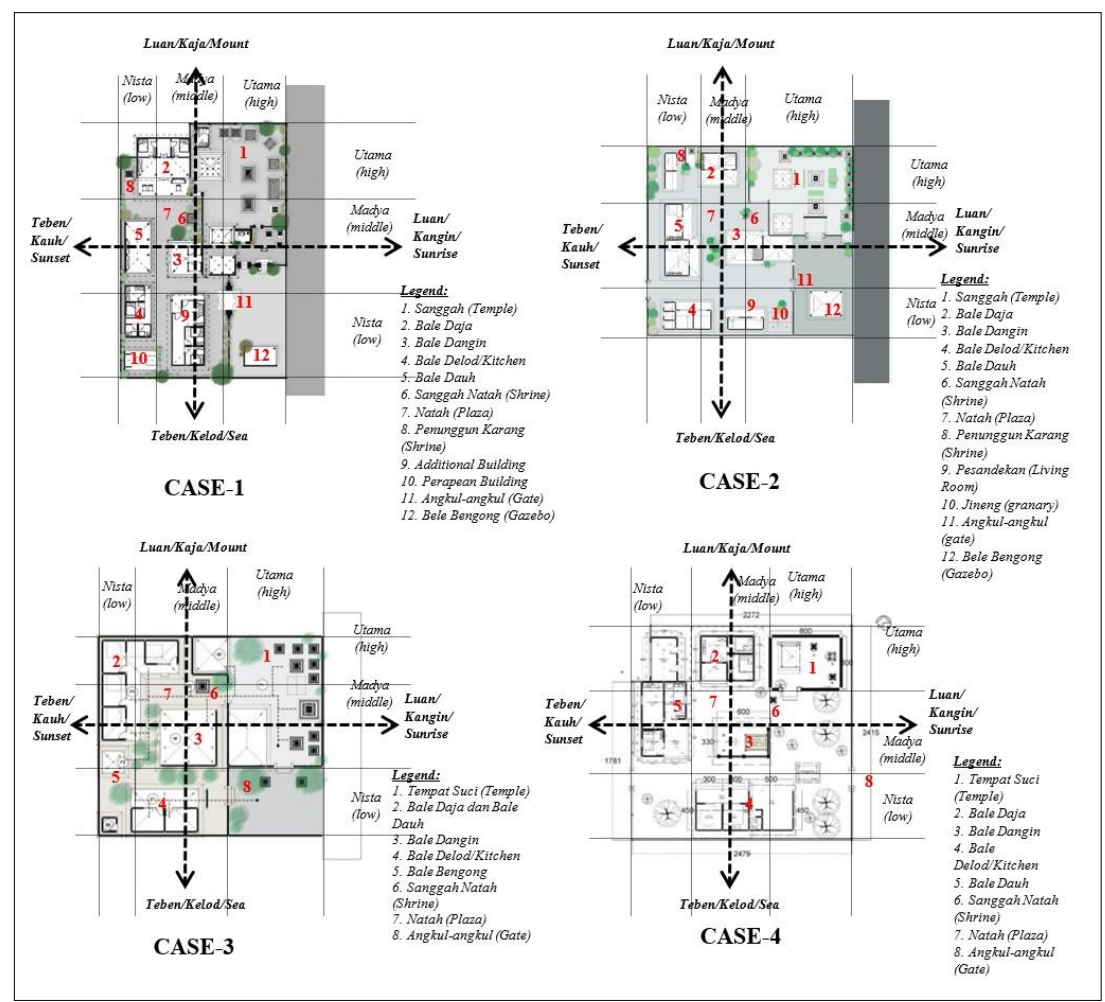

Figure 3. Luan and Teben Concepts on Mass-Zoning of Buildings

(Source: Author, 2020) 
Based on the zoning system of Sanga Mandala, it shows that, the conception of luan is marked by the zoning of the shrine, Bale Daja and Bale Dangin. This is based on the function that is accommodated as well as the community that uses these buildings. Shrine as a space that is used for sacred ritual activities, so that the zoning system is placed in the luan (utamaning utama). Bale Daja which functioned as a parent's bedroom or master bedroom, which in the Hindu-Balinese concept that parents as someone who takes precedence, this concept is in accordance with Putra's statement, that parents who "gave birth" are Guru Rupaka who must be respected (Putra, Alfyananda Kunia Sumarmi \& Singgih, 2018), so the zoning system is in the luan or Utamaning Madya. Bale Dangin which facilitates religious ritual activities such as weddings, birthday and funerals are interpreted as spaces for ritual activities for humans. It is different from Sanggah or the shrine of Balinese ethnic houses which has been explained above whereas a form of ritual activity to God. Therefore, Bale Dangin occupies zoning in the direction of the luan (Kangin/ direction of sunrise), while the concept of teben is identified with physical activities such as kitchen or Bale Delod, Bale Dauh, and other supporting buildings occupying zones in the direction of Teben (Kauh and Kelod). (see Figure 3).

\section{Luan and Teben's Conception Based on Space and Building Transformation}

The development of the traditional architecture of Balinese ethnic housing cannot be separated from the changing of times and social, economic and technology. This has an impact on the contemporary architecture of traditional Balinese ethnic housing. This change according to Santhyasa (2010), in essence culture is not created only once, but continuously. Cultural changes occur in aspects of physical form, social system and the idea system and the change is influenced by several aspects such as economic, social, political and cultural aspects. According to Indriani (2018), Balinese traditional architecture cannot be separated with social spiritual, but social, economic and technological development requires changes that still have traditional guidelines as the soul of the architecture. Related to the changes in traditional architecture, Tarigan (2017) states that changes or the extinction of a culture (traditional architecture) are caused by economic factors, changes in lifestyle and the inability of traditional spaces to meet new activities. According to Rapoport (1969 in Susanta \& Wiryawan, 2016), that the dynamics of architectural change can occur possibly because of two factors, including primary factor and modifying factors/secondary. Primary factor includes socio-cultural factors, meanwhile, modifying factors include climate factors, material factors, technological and construction factors, land factors, etc. The layout development of the residential units is inseparable from the demands for the growing number and needs of the community in Denpasar. This certainly causes the transformation of the layout of each building unit to experience changes such as the addition of space. The addition of a toilet or bathroom in Bale Dauh and Bale Delod as supporting space. The addition of new bedrooms or residential units in the form of residential buildings because of the addition of family members, for example boys who are married and reside in one of these residential units (see Figures 4 and 5). The transformation can also be seen from the merging of two building units into one building unit, namely Bale Daja and Bale Dauh (see Figure 6). Changes in the shape of buildings often occur in units of Balinese ethnic houses buildings that previously used traditional architecture to change into contemporary Balinese, following a growing trend of both material finishing trends and contemporary ornaments (see Figure 7). This is certainly based on the idea that traditional building elements have a low level of resilience and are difficult to obtain, so they are replaced with other building elements. 
The Local Wisdom Study of Luan And Teben Concept on Balinese Ethnic Houses Case Study: Balinese Ethnic Houses in Denpasar, Bali

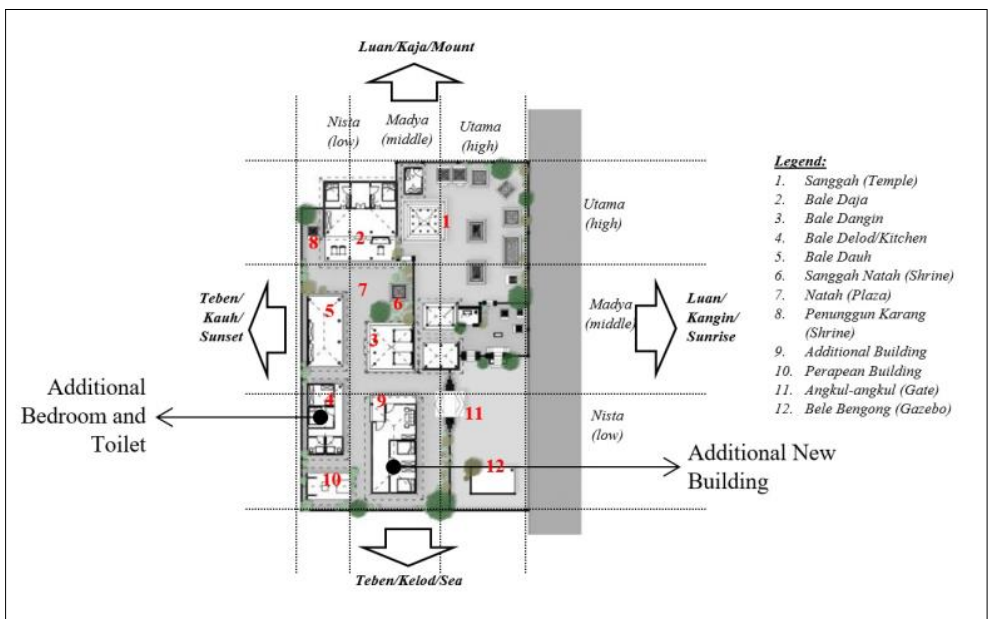

Figure 4. Additional of New Space and Buildings in Cases-1 (Source: Author, 2020)

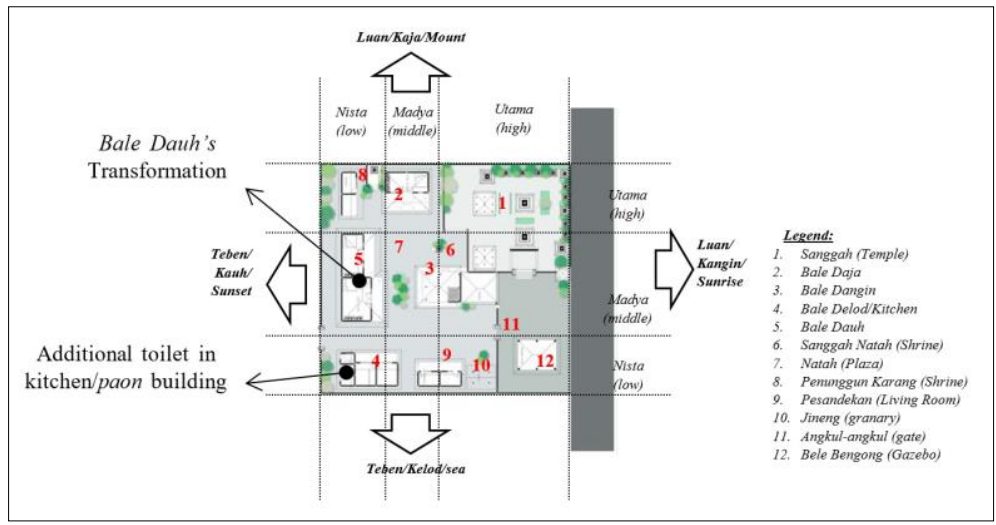

Figure 5. Additional of New Space and Buildings in Cases-2 (Source: Author, 2020)

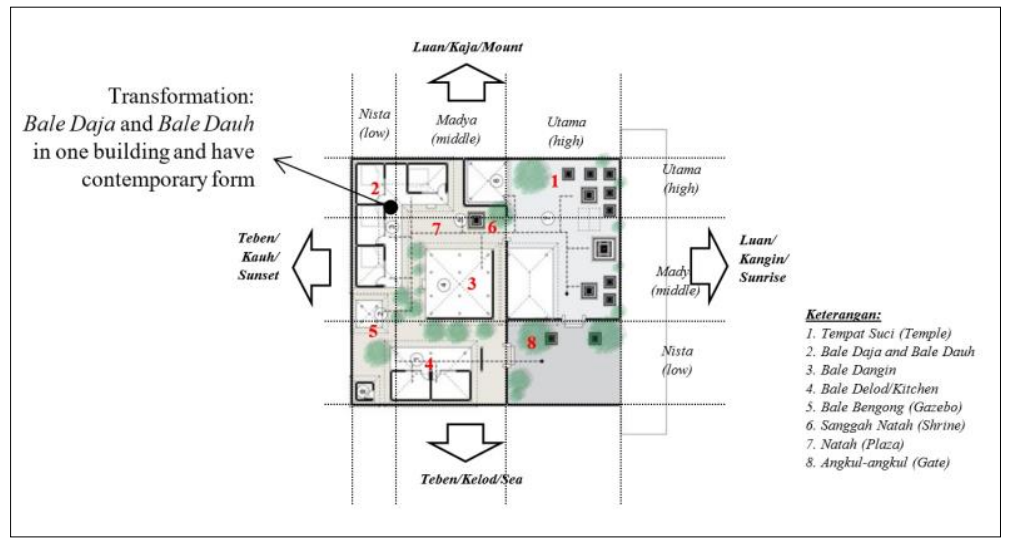

Figure 6. Combination of Two Function Buildings in Cases-3 (Source: Author, 2020) 


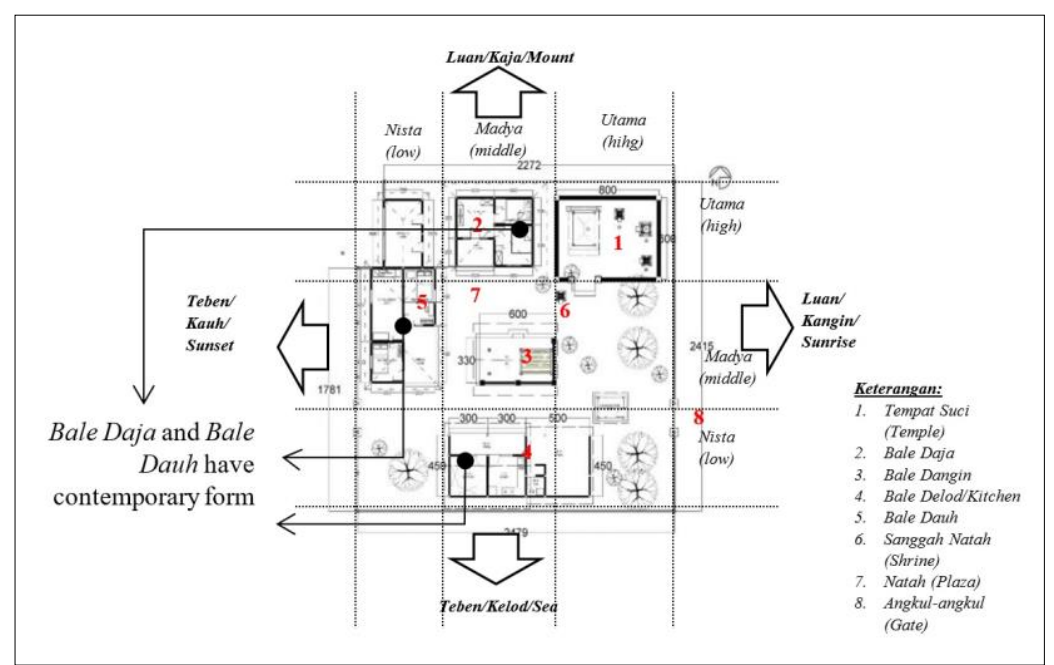

Figure 7. Layout of contemporary building units in Cases-4

(Source: Author, 2020)

This transformation did not completely change the order of traditional Balinese architectural concepts, namely luan and teben. Because understanding of the conception is part of the belief system of the Balinese Hindu community regarding the inevitability values of utama and nista as well as luan and teben. The Balinese have a high spiritual awareness of the true nature of life, one of which is through a harmonious relationship between humans and God which is manifested in the shrine (Suyoga, 2017). This spiritual awareness will become a guide in contemporary changes today. Transformation in the form of merging or adding building units in a single house still uses consideration of luan and teben conceptions. This can be seen from Figure 6, that the addition or in the teben or nista and the merger of Bale Daja and Bale Dauh occur in buildings that have non-traditional shapes such as Bale Daja and Bale Dauh architecture. Bale Dangin as a ritual activity space still holds the role of a traditional building unit, as well as the holy place as a sacred space to be highly considered in this transformation (see Figure 8). This means that the transformation occurs only in building units that have a correlation with human habitation space and tend to the direction of the teben or nista.

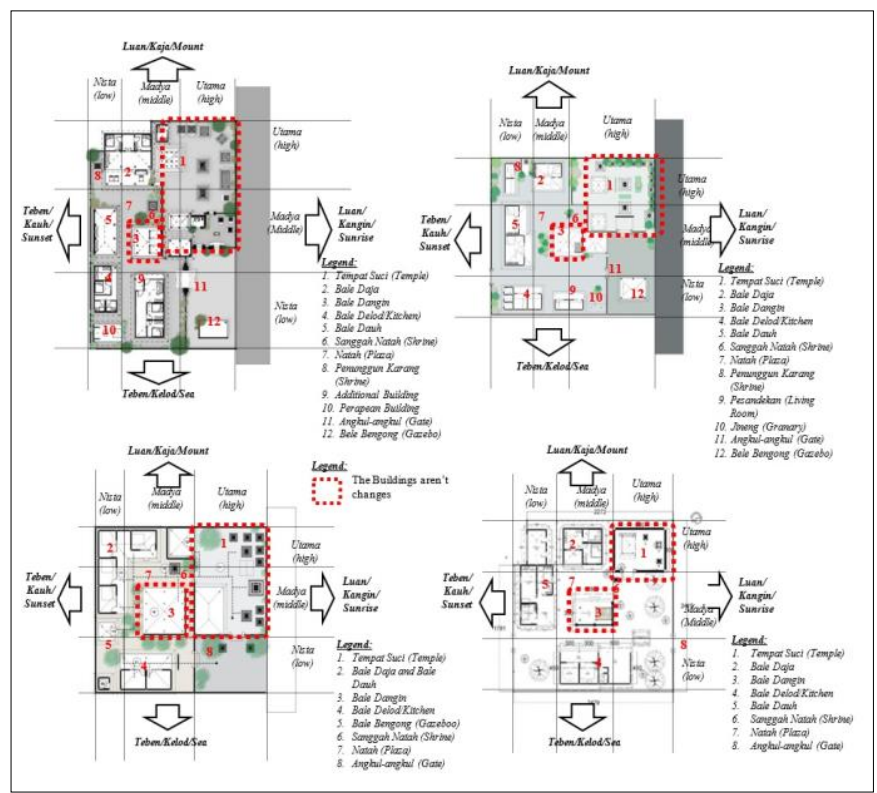

Figure 8. Untransformed Building Units (Source: Author, 2020) 


\section{Luan and Teben's Conception Based on Building Unit Orientation}

The pattern of the building units in the concept of Sanga Mandala forms a "central pattern" visible from the front of each building towards the center (natah/plaza). In the case examined, the concept of natah (plaza) is very strongly seen on the side of each building facing the central space (natah), marked by a transition space (veranda) to strengthen the direction of the building. There are two conceptions underlying the concept of building mass orientation, namely (1) the orientation of each building mass is determined by the layout of the building mass - the building walls reinforce the orientation - oriented to natah (plaza); and (2) the direction of the building mass orientation toward kaja and kangin (luan) Bale Daja towards Kaja, Bale Dangin towards Kaja, Bale Delod towards Kangin and Bale Dauh towards Kaja. According to (Suarya, 2003) and (Wijaya, 2018), a land is an empty space as the center orientation of the building unit's configuration.

From the description above, to determine the direction of the luan and teben based on the orientation of building units using a reference that is the position of the shrine or Sanggah (Kaja - Kangin). The concepts of luan and teben can also be understood through the direction of sunrise and sunset and the direction of the mountain (as a natural orientation which is common in Bali). Buildings that occupy the luan direction have an orientation towards the rising sun and mountains.

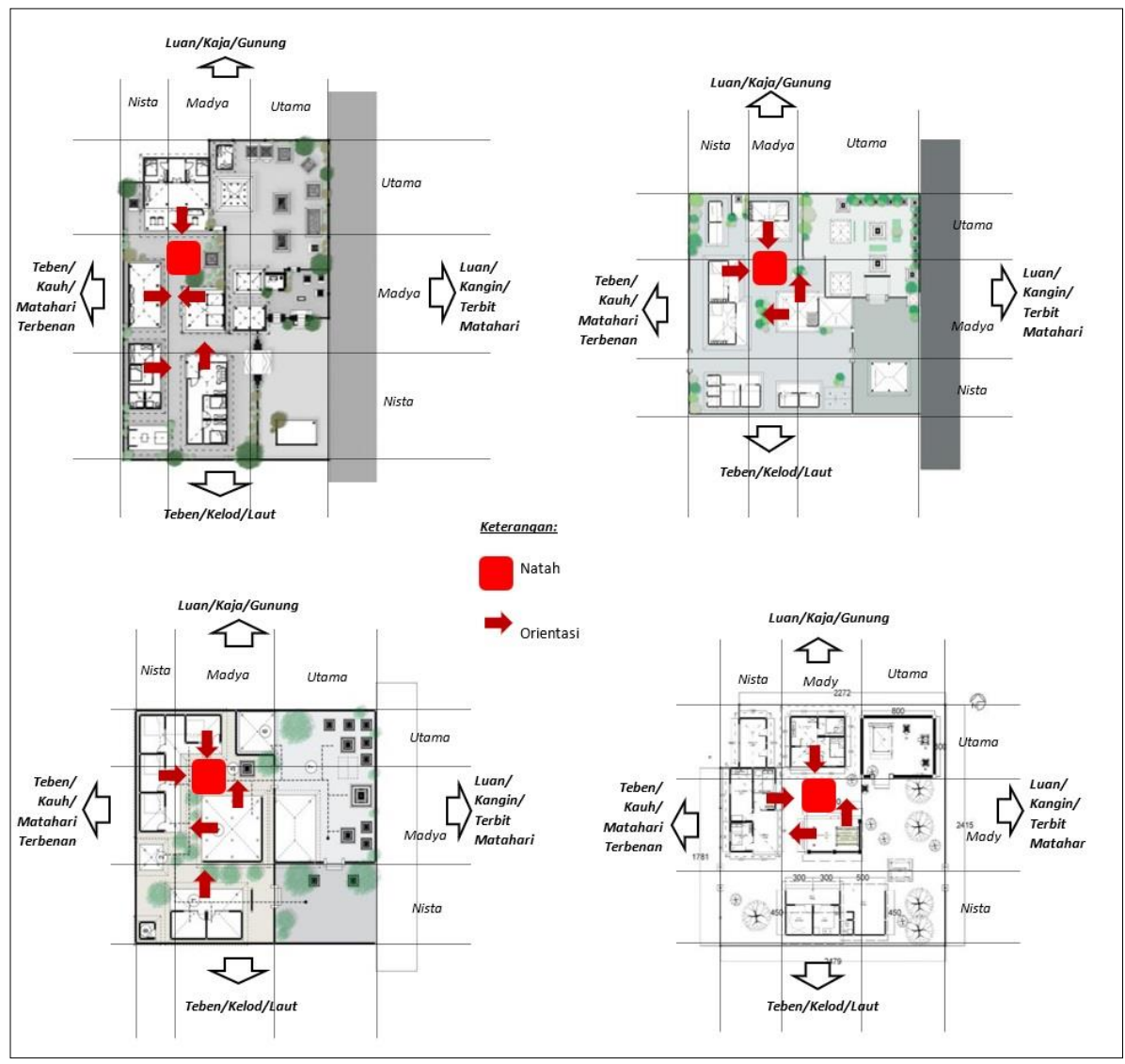

Figure 9. Orientation of The Building Units (Source: Author, 2020) 


\section{Synthesis: Contemporary Concepts of Luan and Teben}

The concepts of luan and teben constitute an axis of dichotomous opposition in the orientation system that is of primary value and contempt in Hindu-Balinese society. The dichotomy of the direction of the main and insignificant values is marked by two main axes namely the natural and ritual axes which divide the spatial layout of ethnic Balinese houses into nine zones called the Sanga Mandala. Conceptually, the order applies clearly and measurably, but in developments in society, such as these case studies in East Denpasar, it is not essential to apply the concept. The direction of luan and teben is not a symmetrical concept but asymmetrical or in the sense that the zoning system is flexible. The direction of luan is marked by the side, which is in the direction of Kaja and Kangin, and vice versa the direction of the teben is the side of which is in the direction of Kelod and Kangin. Longitudinal directions of luan and teben are generally represented by a basic rectangular building, but in this case (East Denpasar) a mass of non-rectangular buildings has been found. The Bale Daja and the Bale Dauh are conceptually separate buildings, but in the field, both are in one building located in the direction of Kaja Kauh. The description implies that the concept of luan and teben is not entirely symmetrical in its application but is asymmetrical based on the condition of the site and the change in the number of residents in one yard. It can be concluded that the concept of luan and teben is evolving in the contemporary context while retaining the central and contemplative aspects of luan and teben in the design of Balinese ethnic residential undergoing a developmental dynamic.

\section{CONCLUSION}

It can be concluded that luan and teben are not entirely in the symmetrical axis where Bale Daja in the Utamaning Madya (luan), nor is the Bale Delod in Nistaning Madya, Bale Dangin in Madyaning Utama, and Bale Dauh in Madyaning Nista. General determinations of luan and teben mean that determinations of luan for Bale Daja and Bale Dangin can still be tolerated if it is the opposite of the Bale Delod and Bale Dauh, therefore it is valued as luan. This contrasts with the conception of direction for the shrine or Sanggah that is absolutely in the corner of Kaja-Kangin. The position and direction of this shrine serve as the starting point in determining the luan and teben of the Balinese ethnic residential housing in the lowland. The dynamics of its development is that the concept of luan and teben are still an integral guideline of the Balinese ethnic house's layout amid its contemporary development.

\section{References}

Arimbawa, W., \& Santhyasa, I. K. G. (2010). "Perspektif ruang sebagai entitas budaya lokal Orientasi Simbolik Ruang Masyarakat Tradisional Desa Adat Penglipuran, Bangli - Bali". Local Wisdom Scientific Online Journal (LWSOJ), 2(4). Retrieved from http://jurnal.unmer.ac.id/index.php/lw/article/view/1385/890

Indriani, M. N. (2018). Eksistensi Kearifan Lokal Hindu Bali Di Era Globalisasi (Arsitektur Bali Dan Subak Kota Denpasar). (M. A. Widyatmika, Ed.). Denpasar: UNHI Press. Retrieved from https://press.unhi.ac.id/wp-content/uploads/2019/08/EKSISTENSI-KEARIFAN-LOKAL-HINDUBALI.pdf

Muhadjir, N. (2002). Metodologi Penelitian Kualitatif Edisi IV (IV). Yogyakarta: Rake Sarasin.

Paramadhyaksa, I. N. W. (2015). "Eksistensi Titik Brahma dalam Tata Ruang Tradisional Bali". In Prosiding Seminar Nasional Tata Ruang dan SPACE\#2. Denpasar: Program Studi Perencanaan Wilayah \& Kota. Retrieved from https://repositori.unud.ac.id/protected/storage/upload/repositori/b5ebfbaf7f4cd720004ad69d1fc9529 a.pdf

Putra, Alfyananda Kunia Sumarmi, S., \& Singgih, S. (2018). "Makna Konsep Catur Guru bagi Suku Tengger sebagai Upaya Pendewasaan Usia Perkawinan (Perspektif Fenomenologi)". Jurnal Pendidikan: Teori, 
The Local Wisdom Study of Luan And Teben Concept on Balinese Ethnic Houses

Case Study: Balinese Ethnic Houses in Denpasar, Bali

I Kadek Merta Wijaya

Penelitian, Dan Pengembangan, 3(1). Retrieved from http://journal.um.ac.id/index.php/jptpp/article/view/11668/5526

Rapoport, A. (1969). House Form and Culture. New Jersey: Prentice Hall.

Rosada; Hariski, M. H. S. (2016). "Asta Bumi Dalam Perspektif Sejarah (Studi Kasus Kota Di Kecamatan Cakranegara Kota Mataram Provinsi Nusa Tenggara Barat)". Paedagoria: Jurnal Kajian, Penelitian Dan Pengembangan Kependidikan, 13(1). $\quad$ Retrieved from http://journal.ummat.ac.id/index.php/paedagoria/article/view/182/150

Santhyasa, I. K. G. (2010). "Ekspresi keruangan budaya lokal: Tinjauan Diakronik Spasial Permukiman Desa Adat Kesiman, Denpasar - Bali". Local Wisdom Scientific Online Journal (LWSOJ), 2(3). Retrieved from http://jurnal.unmer.ac.id/index.php/lw/article/view/1379/884

Siwalatri, N. K. A. (2017). "Representasi Sistem Sosial Masyarakat pada Pola Permukiman Desa Trunyan". RUANG: Jurnal Lingkungan Binaan (SPACE: Journal of the Built Environment), 4(2). https://doi.org/https://doi.org/10.24843/JRS.2017.v04.i02.p07

Suarya, I. M. (2003). "Peranan natah di dalam kehidupan masyarakat Bali". Jurnal Permukiman "Natah," 1(1).

Susanta, I. W., \& Wiryawan, I. W. (2016). "Konsep dan Makna Arsitektur Tradisional Bali dan Aplikasinya dalam Arsitektur Bali". Workshop 'Arsitektur Etnik Dan Aplikasinya Dalam Arsitektur Kekinian.

Suyoga, I. P. G. (2017). "Ruang Ideal Bali dalam Tekanan Globalisasi". Dharmasmrti: Jurnal Ilmu Agama Dan Kebudayaan, 16(1). Retrieved from https://media.neliti.com/media/publications/266335-ruang-idealbali-dalam-tekanan-globalisa-aac486da.pdf

Tarigan, R. A. (2017). "Kajian Makna Fungsi Arsitektur Tradisional: Menuju Arsitektur Lokal". In Seminar Nasional Jelajah Arsitektur Tradisional. Medan: Kementerian PUPR Medan. Retrieved from https://www.academia.edu/35066295/Kajian_Makna_Fungsi_Arsitektur_Tradisional_Menuju_Arsitekt ur_Lokal

Wijaya, I. K. M. (2018). "Discourse On the Concept of Balance of Sakala and Niskala Spaces in Ethnic Balinese Homes". In I. K. Ardhana (Ed.), International Seminar Bali Hinduism, Tradition and Interreligious Studies (pp. 73-80). Denpasar: UNHI Press. Retrieved from https://press.unhi.ac.id/wpcontent/uploads/2018/06/73-80.pdf

Wijaya, I. K. M. (2019). "Konsepsi natah dan lebuh sebagai “Ruang Keseimbangan” dalam arsitektur tradisional Bali". Jurnal Arsitektur ZONASI, 2(2). https:// doi.org/10.17509/jaz.v2i2.14677 